\title{
On the presence of a coastal current of Levantine intermediate water in the central Tyrrhenian Sea
}

\author{
Roberta SERRAVALL ${ }^{a}$, Giovanni Carlo CRISTOFALO ${ }^{\text {b }}$ \\ a Dip. Fisica, Università di Roma "La Sapienza", Piazzale Aldo Moro 2, 00185, Roma, Italy \\ serravall@vaxrom.romal.infn.it \\ b Dip. Geologia, Università di Roma "La Sapienza", Piazzale Aldo Moro 2, 00185, Roma, Italy
}

(Received 16 December 1997, revised 27 October 1998, accepted 10 November 1998)

\begin{abstract}
The hydrological structure and the seasonal variability of marine currents in the Tyrrhenian Sea, off the coasts of Latium, are analysed using a data set obtained during several cruises between February 1988 and August 1990. Of particular interest is the fact that the hydrological surveys show the intermittent presence of a current of Levantine Intermediate Water (LIW) flowing anticlock wise along the Italian slope, at 250-700 m. This current is of particular importance in inferring the pathways of the Levantine Intermediate Water in the western Mediterranean Sea and in particular in the Tyrrhenian basin, downstream of the Strait of Sicily. These phenomena remain an open problem: our observations give support to the Millot's proposed general scheme, on the existence of a general cyclonic circulation of the LIW from the Strait of Sicily to the western Mediterranean, as opposed to a direct injection of LIW towards the Algerian basin. (C) Elsevier, Paris / Ifremer / Cnrs / Ird
\end{abstract}

\section{Tyrrhenian / Levantine Intermediate Water / Margules}

Résumé - Courant côtier d'eau intermédiaire Levantine dans la mer Tyrrhénienne. La structure hydrologique et la variabilité saisonnière des courants marins de la mer Tyrrhénienne, au large des côtes du Latium, sont analysées en utilisant des données obtenues pendant plusieurs croisières, entre février 1988 et août 1990. Le fait particulièrement intéressant est que ces recherches hydrologiques démontrent une présence intermittente du courant LIW (Eau intermédiaire Levantine-Levantine Intermediate Water), circulation cyclonique le long de la pente italienne, à une profondeur de 250 à $700 \mathrm{~m}$. Le courant est particulièrement important pour déduire les trajectoires de l'eau LIW de la mer Méditerranée occidentale et, en particulier, dans le bassin Tyrrhénien, suivant le courant du canal de Sicile. Ces phénomènes représentent encore aujourd'hui un problème ouvert. Nos observations confirment le schéma général proposé par Millot sur la circulation générale cyclonique de l'eau LIW du canal de Sicile vers l'ouest de la mer Méditerranée, contrairement à l'entrée directe de l'eau LIW dans le Bassin algérien. (C) Elsevier, Paris / Ifremer / Cnrs / Ird

Tyrrhénienne / eau intermédiaire Levantine / Margules

\section{INTRODUCTION}

The presence of a Levantine Intermediate Water current flowing off the coasts of Latium in the central Tyrrhenian Sea is analysed in this study. This deep isolated basin in the western Mediterranean Sea (figure I) is almost triangular in shape and is surrounded by the Italian peninsula to the northeast and east, by Sicily to the south, by Sardinia and Corsica to the west and finally by the Channel of Corsica to the north. The Tyrrhenian Sea has a com- 


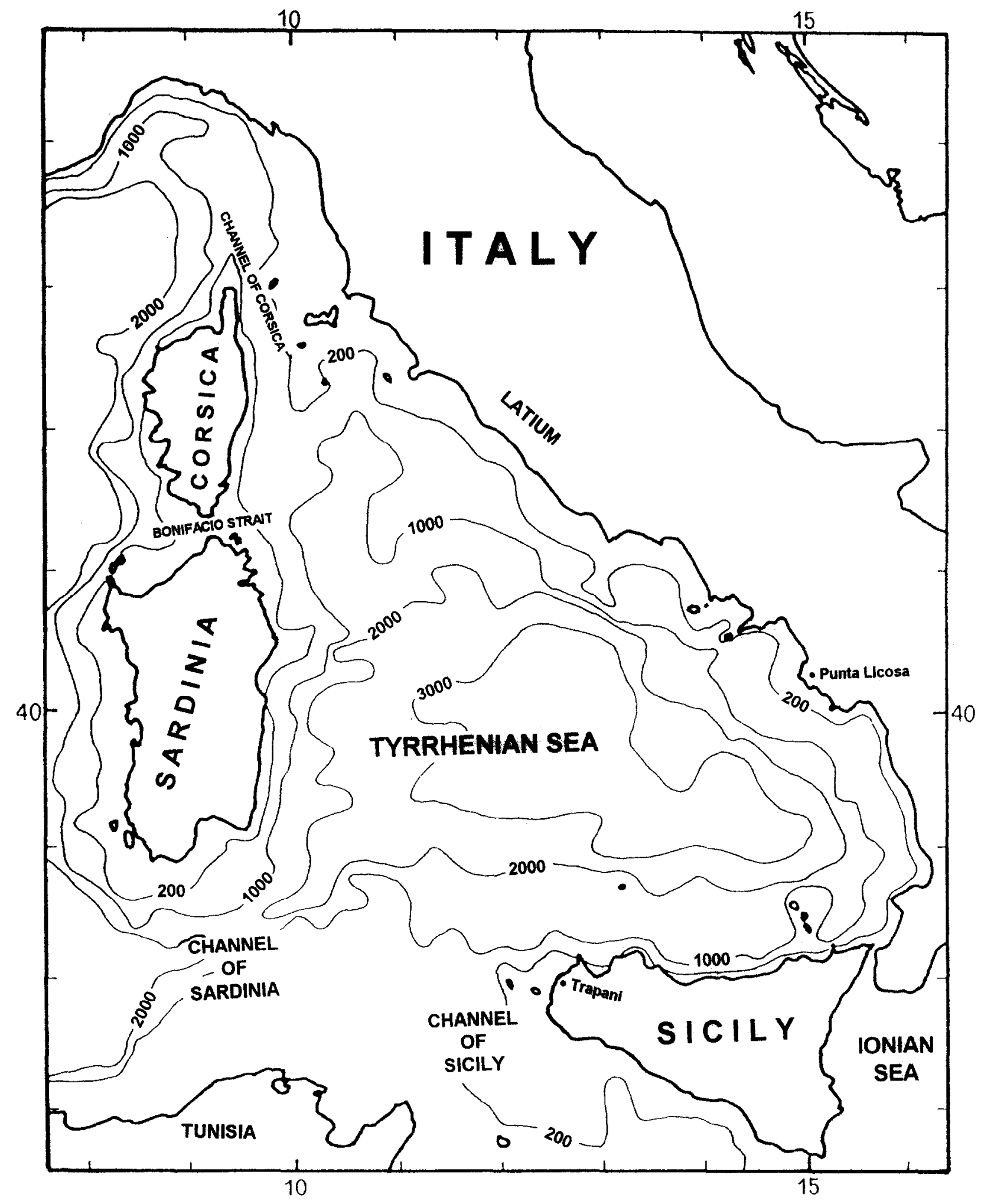

Figure 1. The Tyrrhenian Sea map, depths in metres. 
plex bottom topography, with its deepest part $(3750 \mathrm{~m})$ restricted around $12^{\circ} \mathrm{E}$ and $39^{\circ} \mathrm{N}$.

The Tyrrhenian Sea is connected with the Algerian basin through the Sardinia Strait (with a depth of $2000 \mathrm{~m}$ and a width $\approx 290 \mathrm{~km}$ ) and with the Ligurian Sea, through the Channel of Corsica.

Although the Mistral (N-NW) plays the dominant role $[16,23]$, the other winds blowing across this basin are the Scirocco (SE), Libeccio (S-SW), Ponentino (W), and Tramontana $(\mathrm{N})$. These forcings give rise to large-scale weak cyclonic/anticyclonic circulation systems, although many observations show that along the Italian coasts there is a prevalent anticlockwise current [18, 22]. Moreover, the effect of strong Mistral bursts passing between Sardinia and Corsica is to originate two counter-rotating gyres in the west/middle of the basin, east of the Bonifacio Strait $[22,26]$.

From a hydrological point of view, the Tyrrhenian Sea, like the rest of the western Mediterranean, is essentially composed of four superimposed water layers [28]:

a) the superficial layer consists of relatively fresh water of Atlantic origin, Modified Atlantic Water (MAW), down to $\approx 200 \mathrm{~m}$ (potential temperature $\vartheta \approx 13.5-$ $13.9^{\circ} \mathrm{C}$; salinity $S \approx 38.0-38.5$; potential density $\sigma \approx$ $27.0-28.9$, as is clearly marked in atlases, [10]);

b) the underlying layer is composed of Levantine Intermediate Water (LIW). It is usually found throughout the Mediterranean Sea between $\approx 250 \mathrm{~m}$ and $\approx 700 \mathrm{~m}(\vartheta \approx$ $13.5-13.9^{\circ} \mathrm{C} ; S \approx 38.45-38.75 ; \sigma \approx 29.00-29.10$ ). A mixed water mass of $\approx 50-100 \mathrm{~m}$ thickness can also be found between MAW and LIW, but in the following we will schematically assume the MAW to be $\approx 250 \mathrm{~m}$ thick and the LIW layer to be $\approx 450 \mathrm{~m}$ thick [10];

c) a denser and less salty water called Western Mediterranean Deep Water (WMDW) is present between $\approx 700 \mathrm{~m}$ and $\approx 3000 \mathrm{~m}[13,17,18,28]$. The characteristic properties of the WMDW are $\vartheta \approx 12.90-13.50^{\circ} \mathrm{C}, S \approx 38.4-$ $38.6, \sigma \approx 29.10-29.11$;

d) finally the bottom water, with its source in the northwestern Mediterranean, reaches depths of up to $\approx 4200 \mathrm{~m}$ [28].

In this study, we focus our attention on the LIW pathway in the Tyrrhenian Sea. This water mass is formed during winter in the eastern Mediterranean Sea, near the island of Rhodes, as a result of intense water cooling and evaporation processes. LIW is not influenced by fluvial contributions and is therefore characterized by a salinity maximum. After its formation, LIW spreads and can be found throughout the Mediterrancan Sca. LIW crosscs the Channel of Sicily through two passages, the greater flow occurring in the decp castern canyon close to the Sicilian shelf $[2,14,15]$, feeding the intermediate layers of the western Mediterranean Sea [14, 15, 18, 20, 25, 28].

LIW dynamics, particularly in the Tyrrhenian Sea, are an interesting open problem. Indeed, to our knowledge, in the western Mediterranean Sea they can be described using a classical schema [28] or a more recent idea of Millot [18]. The former suggests that the flow of LIW, after passing through the central Ionian basin, crosses the Strait of Sardinia and flows along the continental slope of North Africa toward the Strait of Gibraltar. The second one suggests that the LIW flow is driven by the Coriolis force and the topography and also encounters large-scale turbulent flows. Following this schema the LIW flows anticlockwise along the continental slope all over the Mediterranean Sea; after passing through the Channel of Sicily, it deviates along the Sicilian slope, before flowing along the Italian slope up to the Channel of Corsica. Considering that the width and depth of this Channel are not sufficient to allow the draining of all the water entering the basin, LIW probably continues, at least in part, flowing southward along the continental slope of Corsica and Sardinia, again following the bathymetry. In such a context, Hopkins [12] estimated that $\approx 2 / 3$ of LIW entering the Tyrrhenian Sea recirculates across the Sardinia Strait and $\approx 1 / 3$ exits northward through the Corsica Channel. Garzoli and Maillard [8] found that an equal quantity of LIW enters and leaves the Tyrrhenian Sea. Furthermore, in a recent oceanographic cruise AIS96 (Atlantic Ionian Stream - August 1996) on board the $R / V$ Alliance (NATO, SACLANT Undersea Research Centre) in the Sicily Channel and Ionian Sea, strong average velocities of LIW were measured with the Acoustic Doppler Current Profile Vessel Mounted (ADCP VM) as well as with classical CTD measurements. In the narrowest part of the Sicily Channel (figure 1), an average velocity of about $20-25 \mathrm{~cm} \mathrm{~s}^{-1}$ at a depth of $\approx 200-300 \mathrm{~m}$ was measured. Moreover, an average velocity of $\approx 15-20 \mathrm{~cm} \mathrm{~s}^{-1}$ in direction N-NW, offshore Trapani, was found at $\approx 300$ $400 \mathrm{~m} \mathrm{[25].}$

Also of interest is the recent numerical investigation of $\mathrm{Wu}$ and Haines [29] in which the LIW distribution in the Mediterranean Sea and its behaviour in the western basin after crossing the Channel of Sicily is analysed. In the Algerian basin, west of Sardinia, two LIW boundary currents are formed that flow northward (along the western 


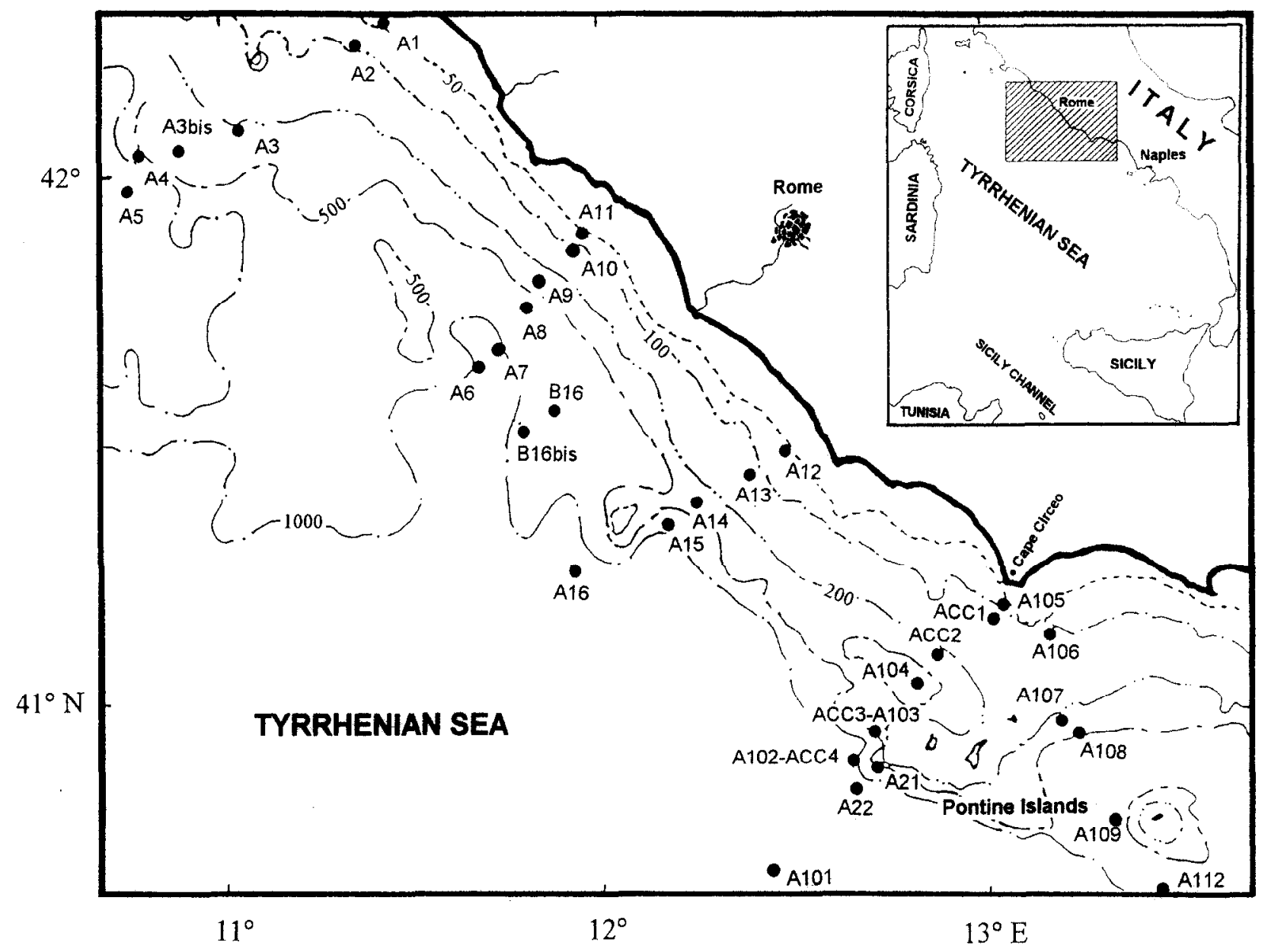

Figure 2. General map with detailed bathymetry of the Tyrrhenian Sea near the coasts of Latium (depths in metres) and positions of CTD stations.

slopes of Sardinia and Corsica) and westward, along the North African slope. However, no circulation of LIW along the Italian slope has been described. In general, numerical information can be said to be associated with very different hydrological distribution and circulation patterns in the Tyrrhenian Sea, which have so far not been discussed on the basis of adequate data sets.

It is consequently of interest that, in 1988-1990, several routine oceanographic cruises (University of Rome "La Sapienza") measured currents off the I atium slopes (figure 2; $[3,24]$ ). In these hydrological CTD data, the LIW layer can he identified by its salinity maximum. From the vertical maps of potential isopycnals (figures 3a-d), an along-slope northward coastal flux at intermediate depths is evident, the analysis of which is the purpose of this article.
This flow is not totally unexpected. Indeed Hopkins and G.O.N.E.G. [11] report that LIW has been found repeatedly in the Tyrrhenian Sea, and similar results are evident in De Maio et al. [5]. Moreover, in a hydrological transect off Punta Licosa, about $200 \mathrm{~km}$ south-east of Naples, Astraldi and Gasparini [1] found evidence of a LIW coastal vein at about $350 \mathrm{~m}$, with a slow northward velocity of about $2 \mathrm{~cm} \mathrm{~s}^{-1}$.

It may thus be concluded that the presence of LIW in the Tyrrhenian Sea is not totally unexpected, but no clear evidence of strong northward velocities along the slopes has sn far been produced. For this reason the LIW dynamics downstream of the Sicily Channel must still be considered as an open problem [14]. In such a context, the goal of this paper is to describe the presence of LIW slope currents in the central Tyrrhenian Sea, which is a novelty as 
Table 1. Synthesis of hydrological data.

\begin{tabular}{|c|c|c|c|c|c|c|}
\hline $\begin{array}{l}\text { Cruise } \\
\text { (Date) }\end{array}$ & $\begin{array}{l}\text { Stations } \\
\text { of interest } \\
\text { for LIW }\end{array}$ & $\begin{array}{c}\text { Distance between } \\
\text { stations } \\
{[\mathbf{k m}]}\end{array}$ & $\begin{array}{l}\text { Estimated no-motion } \\
\text { layer depth } \\
{[\mathrm{m}]}\end{array}$ & $\begin{array}{l}\text { LIW thickness } \\
\text { range } \\
{[\mathrm{m}]}\end{array}$ & $\begin{array}{c}\text { Estimated } \\
\text { geostrophic velocity } \\
{\left[\mathrm{cm} \mathrm{s}^{-1}\right]}\end{array}$ & $\begin{array}{c}\text { Estimated } \\
\text { flux } \\
{[\mathrm{Sv}]}\end{array}$ \\
\hline "Antares" & A7-A6 & 8 & 325 & $300-700$ & 15 & 0.50 \\
\hline$(24 / 2 / 88-3 / 3 / 88)$ & A $108-A 109$ & 10 & 375 & $300-600$ & 1 & 0.02 \\
\hline "Altair" & $\mathrm{A} 22-\mathrm{A} 101$ & 34 & 225 & $325-700$ & 3 & 0.40 \\
\hline$(25 / 11 / 88-3 / 12 / 88)$ & A $15-A 16$ & 20 & 300 & $425-750$ & 1 & 0.06 \\
\hline "Arcturus" & A 102-A22 & 4 & 350 & $300-500$ & 10 & 0.10 \\
\hline$(18 / 3 / 89-24 / 3 / 89)$ & B16-B $16 \mathrm{his}$ & 7 & 330 & $350-600$ & 4 & 0.17 \\
\hline $\begin{array}{l}\text { "Aldebaran" } \\
(15 / 7 / 89-24 / 7 / 89)\end{array}$ & A $15-A 16$ & 21 & 200 & $400-600$ & 6 & 0.40 \\
\hline "Andromeda" & ACC3-ACC4 & 5 & 250 & $300-500$ & 3 & 0.05 \\
\hline$(12 / 9 / 89-25 / 9 / 89)$ & A15-A 16 & 30 & 75 & $350-550$ & 10 & 0.90 \\
\hline "Bootes" & A6-A7 & 7 & 500 & $500-800$ & 2 & 0.05 \\
\hline$(21 / 8 / 90-30 / 8 / 90)$ & $\mathrm{ACC} 3-\mathrm{ACC} 4$ & 7 & 200 & $275-500$ & 8 & 0.19 \\
\hline
\end{tabular}

far as field observations in the Tyrrhenian near the coasts of Latium are concerned. It has to be stressed that these coastal currents are not only of interest in themselves but also support Millot's general idea of Mediterranean Sea circulation $[6,14,18]$.

\section{DATA AND METHODS}

The most interesting part of the hydrological data (CTD and bottles) collected during the oceanographic cruises off the Latium coasts is summarized in table I. The LIW layer has a characteristic $\vartheta / S$ profile throughout the Mediterranean Sea, as described above. Due to the importance of large-scale coastal morphology, smaller-scale effects can be disregarded and so a classical gcostrophic method can be used here to analyse such flows. From the isopycnals shown in figures 3a-d, an cstimate of the density difference between LIW and MAW:

$\frac{\Delta \rho}{\rho}=\frac{\rho_{L I W}-\rho_{M A W}}{\rho} \approx 2 \times 10^{-4}$

is obtained. The baroclinic velocity is:

$$
\begin{aligned}
C & =\left(g \frac{\Delta \rho}{\rho} \frac{h_{M A W} h_{L I W}}{h_{M A W}+h_{L I W}}\right)^{1 / 2} \\
& =\left(g^{\prime} \frac{h_{M A W} h_{L I W}}{h_{M A W}+h_{L I W}}\right)^{1 / 2}=0.6 \mathrm{~ms}^{-1}
\end{aligned}
$$

finally, the internal Rossby radius $R$ is:

$R=\frac{C}{f} \approx 6 \mathrm{~km}$ where as usual $g^{\prime}=g \Delta \rho / \rho$ is the reduced gravity, $\rho_{M A W} \rho_{L I W}$ and $h_{M A W}, h_{L I W}$ are the densities and layer thicknesses of MAW and LIW respectively and finally $f=10^{-4} \mathrm{~s}^{-1}$ is the Coriolis parameter at these latitudes.

From potential isopycnal analysis (figures $3 \mathrm{a}-\mathrm{d}$ ), we see that there is a rather flat layer around $200-300 \mathrm{~m}$. Moreover, figure 4 shows that the $\mathrm{O}_{2}$ reaches its minimum value at about $200-300 \mathrm{~m}$ and remains constant below. Using Dietrich's method [7], we decided to set the nomotion level at this depth. From this choice a reasonable absolute velocity for the various water layers can be evaluated. The resulting velocity jump $\Delta v$ :

$\Delta \mathrm{v} \cong \frac{g}{f} \frac{\Delta \rho}{\rho} \tan \alpha=\frac{g^{\prime}}{f} \tan \alpha$

can then be computed for each transect, $\alpha$ being the isopycnal slope [21].

The main result of this work is that in our measurements the isopycnal slope in some hydrological sections clearly indicates the presence of a vigorous current of LIW, with considerable N-NW fluxes (table I). This new determination of such currents is of considerable interest for the dynamics of water masses in the Mediterranean Sea, as it gives support to Millot's [18] schema.

In these measurements, the velocity and the flux of LIW significantly show a strong variability, either due to seasonal changes or to instabilities of currents flowing along a steep slope. Also to be taken into account is the difficulty of following this mid-depth current through stations planned for the purpose of routine measurements, and not to research a detailed "vein" of LIW water. Indeed the LIW is not fully observable in all the CTD data but is 


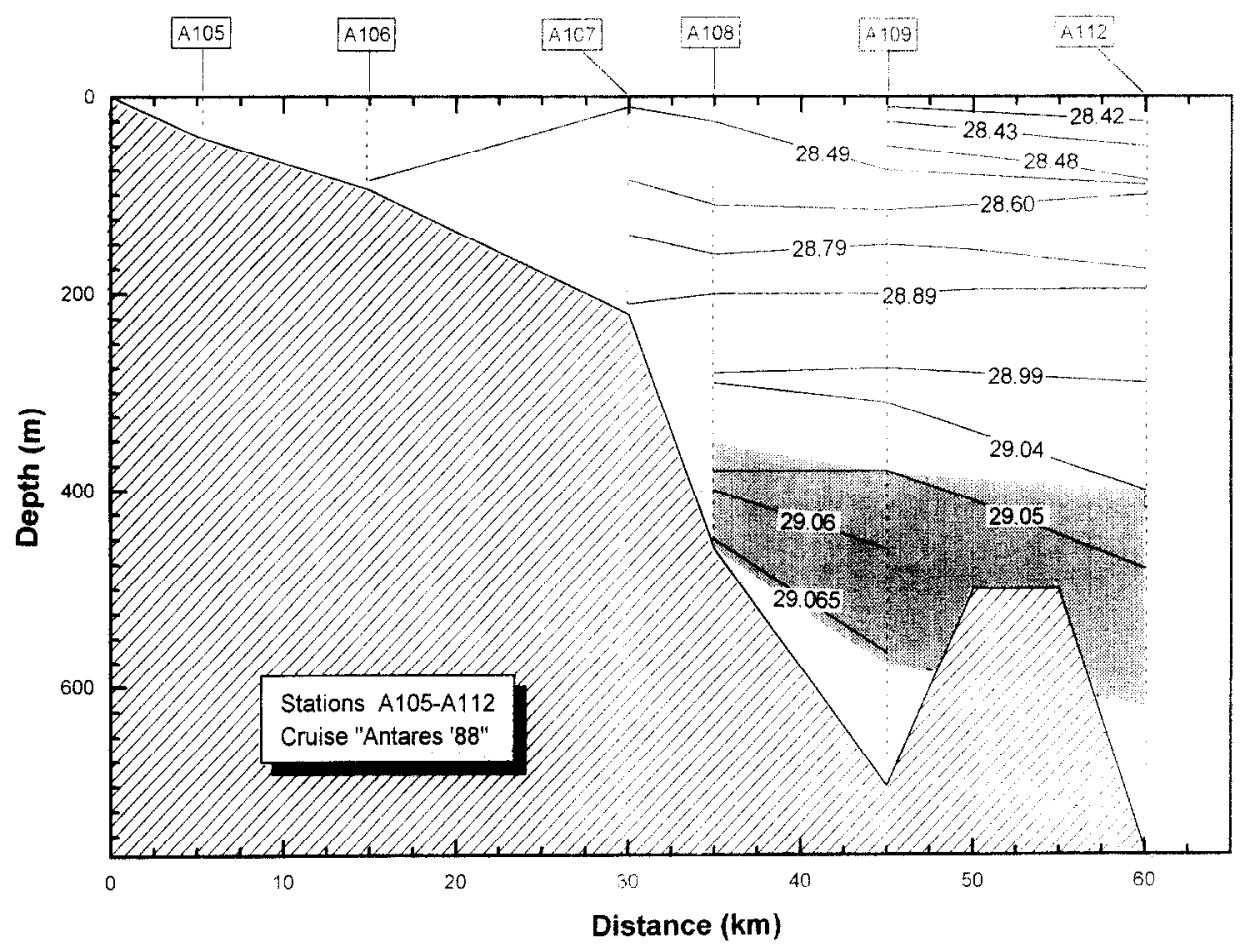

Figure 3a. Potential isopycnals for sections A 105-A112 (Cruise ANTARES 1988). The dashed zone represents the water mass corresponding to LIW.

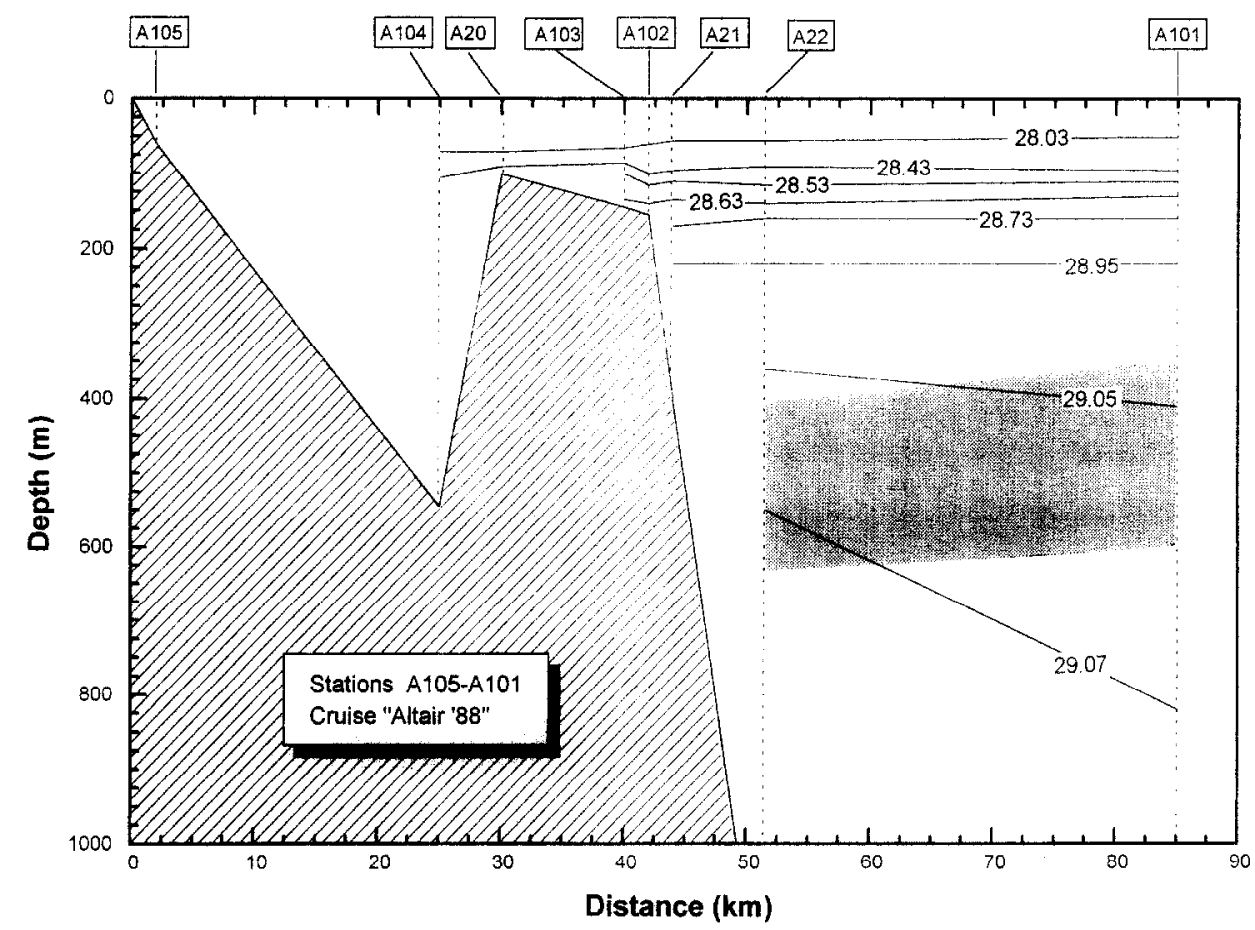

Figure 3b. Potential isopycnals for sections A105-A 101 (Cruise ALTAIR 1988). The dashed zone represents the water mass corresponding to LIW. Note the unusual behaviour of isopycnals versus LIW, an effect due to current deflection caused by the Pontine Islands. 


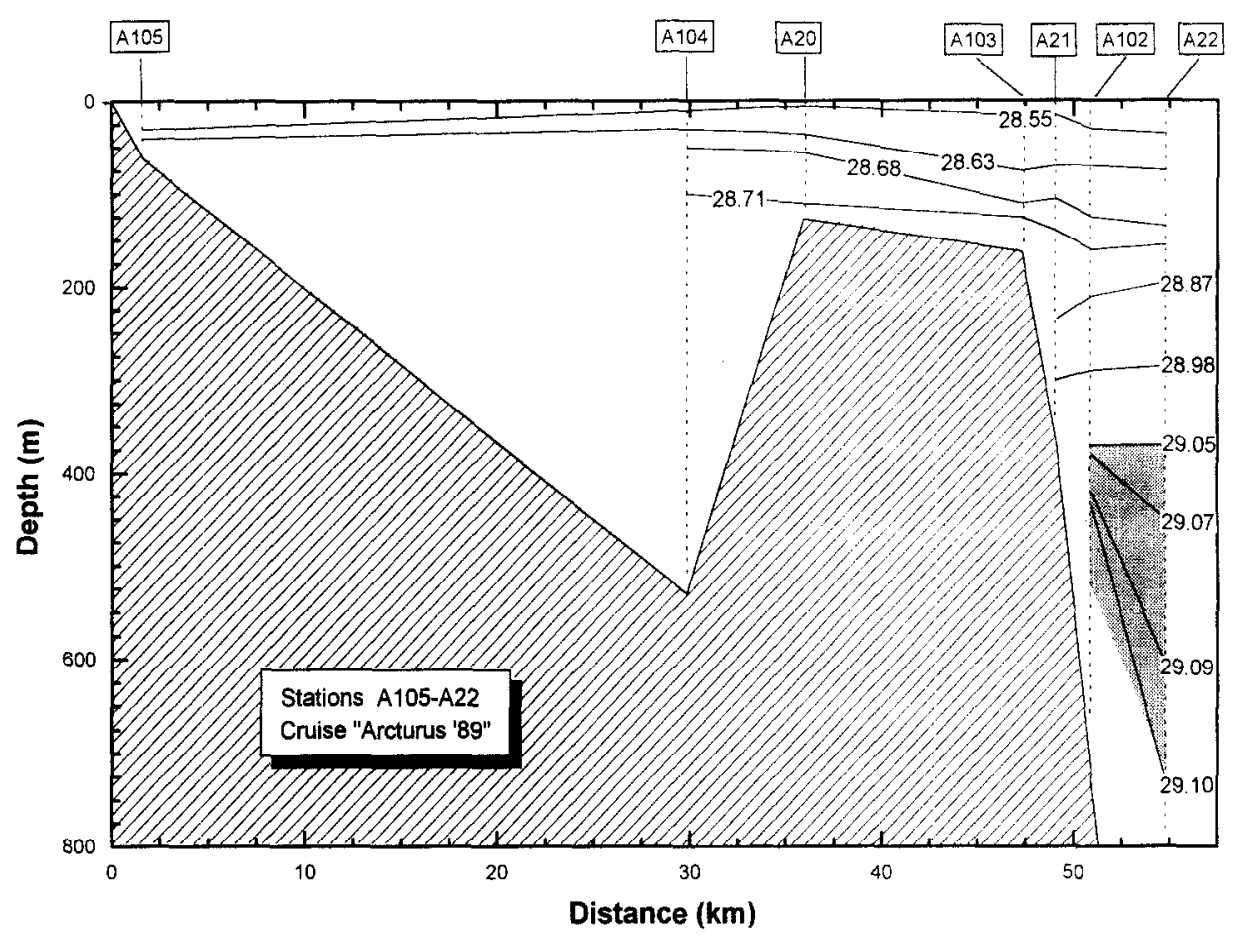

Figure 3c. Potential isopycnals for sections A105-A22 (Cruise ARCTURUS 1989). The dashed zone represents the water mass corresponding to LIW.

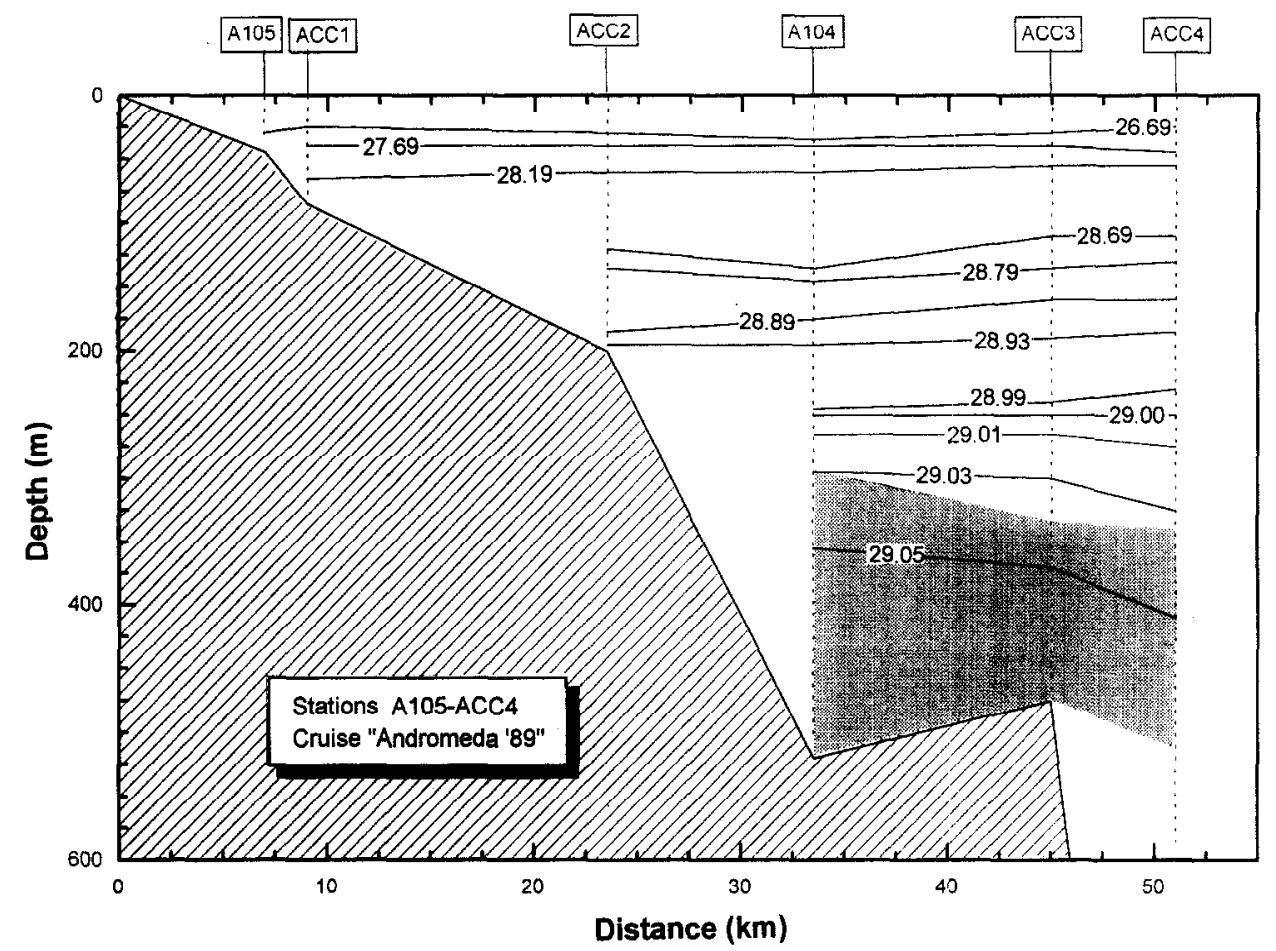

Figure 3d. Potential isopycnals for sections A105-ACC4 (Cruise ANDROMEDA 1989). The dashed zone represents the water mass corresponding to LIW. 


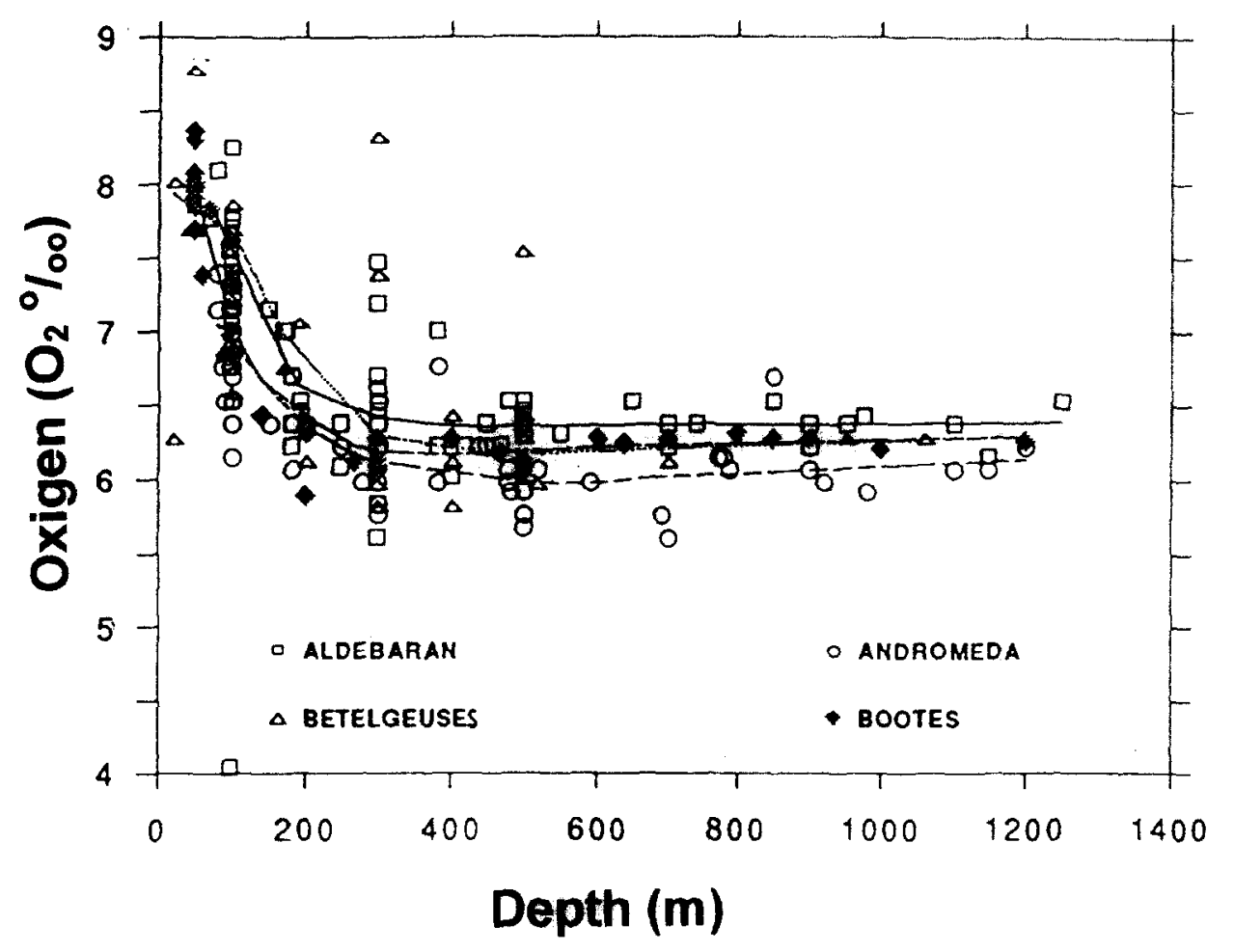

Figure 4. Totality $\mathrm{O}_{2}$ as a function of depth

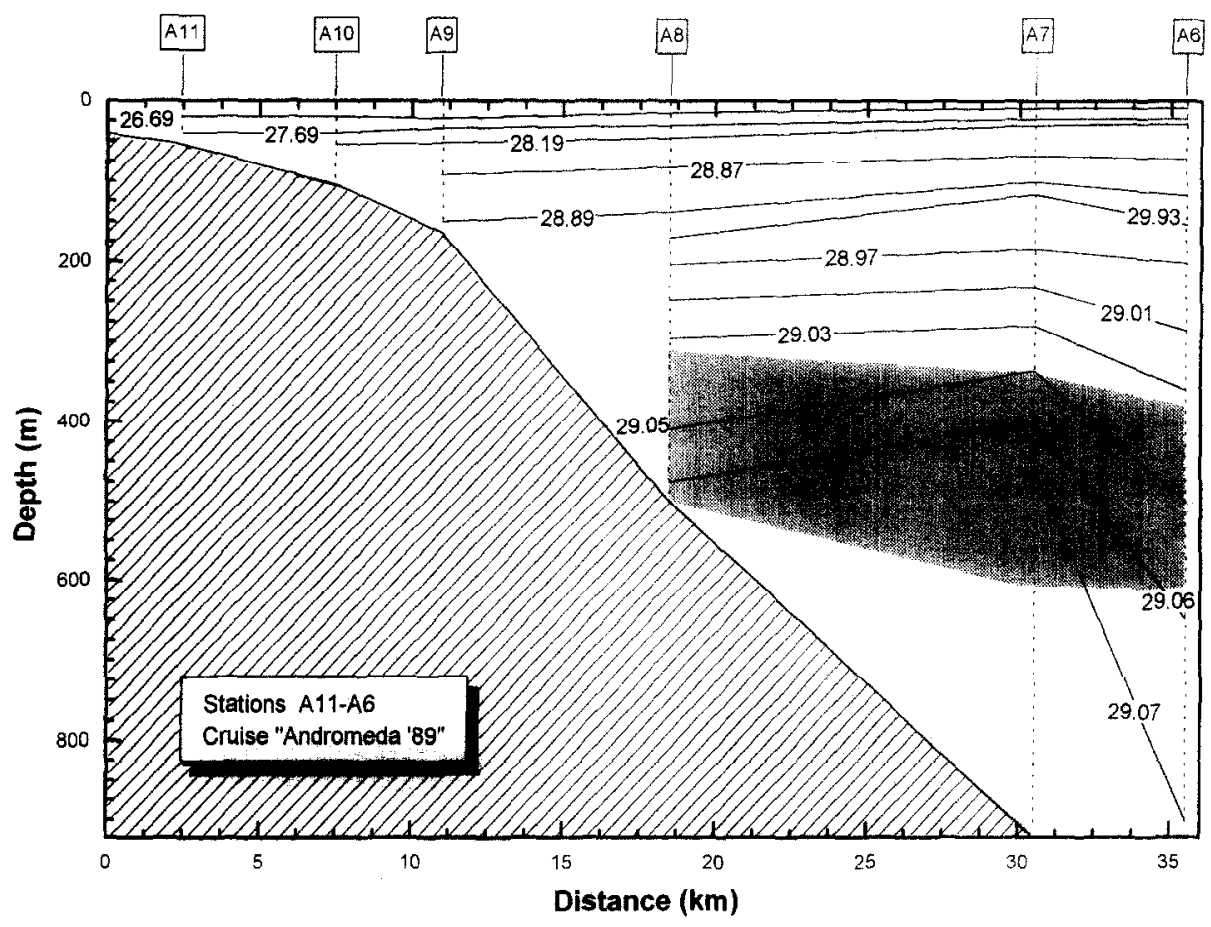

Figure 5. Potential isopycnals for sections A11-A6 (Cruise ANDROMEDA 1989). The dashed zone represents the water mass corresponding to LIW. 
usually visible only in a couple of stations of the various hydrological transects, often the most external ones. It is thus clear that this LIW core identification is not the most significant one. In figures $3 \mathrm{a}-\mathrm{d}$, we show that the LIW vein corresponding to one of the transects is the one with the most evident LIW, located between Cape Circco and Pontine Islands. Moreover, the difference between the isopycnals of this Pontine Islands transect is compared with those of a northern transect (figure 5), where the effect of a vigorous surface current, flowing castward from Sardinia and attaining the Latium coasts before turning northward as a coastal current [22], can be casily detected.

\section{CONCLUSIONS}

Even if we cannot fully discuss the presence of a "vein of LIW" flowing anticlockwise along the Italian slopes in the central Tyrrhenian Sea, since our measurements were not designed to consider the entire phenomenon, the presence of these coastal velocities of LIW at about $500 \mathrm{~m}$ is rather interesting, because this is somehow expected but never clearly observed. It is thus interesting to compare our data with results of theoretical models; the simplest ones come from Gill's observation [9] that a discontinuity on an interface (i.e. due to winds or baroclinic tidal flows over a ridge, or baroclinic currents passing through a strait) of a rotating two-fluid system can generate shorttime and long-time waves. In our case, the flows are rather regular, since in their long trip from the Rhodes gyre the transient currents have probably lost their importance. The long-term solutions can then theoretically be seen as currents propagating along-slope $[4,9,27]$. This is valid both for barotropic phenomena and for a gencral baroclinic system. This is not only a theoretical problem, since in many papers $[6,18,19,29]$ it is clcarly stated that the pathways of LIW in the western Mediterranean, and in particular in the Tyrrhenian basin, have only been summarily investigated. In particular, the study of the thermohaline circulation in the wholc Mediterranean Sea is a problem of fundamental importance, and is still uncertain and controversial [6, 19, 28, 29]. From our measurements, we found the presence of a current of LIW ncar the coasts of Latium, even if it is not totally clear how wide the vein is. These measurements are of interest since the literature contains insufficient indications concerning the presence of LIW north and south of the Latium coasts, whilc the presence of LIW in the whole Tyrrhenian basin is a rather commonly accepted fact. In general, these measurements support Millot's idea, although this work suggests the utility of planning further ficld measurements to elucidate such fundamental problems.

\section{Acknowledgements}

This work was proposed by Prof. Salusti; the authors wish to thank him for his collaboration in an early stage of this study. Moreover, they wish to thank M. Astraldi and G.P. Gasparini, for their precious information about the presence of LIW south of the Gulf of Naples, and S. Sparnocchia for several suggestions. Thanks are also due to the anonymous referees whose suggestions greatly contributed to the improvement of the paper.

\section{REFERENCES}

[1] Astraldi M., Gasparini G.P., TEMPO 3, unpublished data (1991), October-November.

[2] Béthoux J.P., Prieur L., Nyffeler F., The water circulation in the north-western Mediterranean Sea, its relations with wind and atmospheric pressure, in: Nihoul J.C.J. (Ed.), Hydrodynamic of semi-enclosed seas, Elsevier, 1982, 129-148.

[3] Bignami F., Manzella G.M.R., Salusti E., Sparnocchia S., Circolazione delle acque, in: Il mare del Lazio (oceanografia fisica e chimica, biologia e geologia marina, clima meteomarino, dinamica dei sedimenti e apporti continentali) (Ed.) by Università degli Studi di Roma "La Sapienza" e REGIONE LAZIO, tipografia Borgia, 1996, 1-23.
[4] Chusman-Roisin B., Introduction to geophysical Fluid Dynamics, Prentice Hall, Englewood Cliffs, New Jersey, 1994, $320 \mathrm{p}$.

[5] De Maio A., Moretti M., Sansone E., Spezie G., Vultaggio M., Dinamica delle acque del Golfo di Napoli, Presentazione dei dati ottenuti dal 1977 al 1980, Oceanographic data of Gulf of Naples, 1977-1980, Annuali della facoltà di Scienze, Istituto Universitario Navale, appendice N.2 al volume IL-L, 1981, Napoli.

[6] EUROMODEL Group, written by Crepon M., Martel F., Progress from 1989 to 1992 in understanding the Circulation of the Western Mediterranean Sea, Oceanologica Acta, 18, 2 (1995) 255-271. 
[7] Fomin L.M., The Dynamic Method in Oceanography. Elsevier. New York, 1964, 212 p.

[8|Garzoli S., Maillard C., Winter circulation in the Sicily and Sardinia Straits region, Deep-Sea Res. 26 (1979) 933-954.

[9] Gill A.E., Adjustment under gravity in a rotating channel, J. Fluid Mech. 77, 3 (1976) 603-621.

[10] Guibout P., Atlas hydrologique de la Méditerranée, IFREMER and SHOM (Ed.), Paris, 1987, 150 p.

[11] Hopkins T.S., G.O.N.E.G. (Gulf of Naples Ecological Group), The existence of the Levantine Intermediate Water in the Gulf of Naples", XXV Congress and Plenary Assembly of Split (22-30 October 1976), Rapp. Comm. Int. Mer Medit. 24, 2 (1977).

[12] Hopkins T.S., Recent observations on the intermediate and deep water circulation in the southern Tyrrhenian Sea, Oceanologica Acta, Special issue, 9 (1988) 41-50.

[13] L eamann K.D., Schott F.A., Hydrngraphic structure of the convective regime in the Gulf of Lions: Winter 1987, J. Phys. Oceanogr. 21 (1991) 575-598.

[14] Manzella G.M.R., Gasparini G.P., Astraldi M., Water exchange between the eastern and western Mediterranean through the Strait of Sicily, Deep-Sea Res. 35, 6 (1988) 10211035 .

[15] Manzella G.M.R., The Seasonal Variability of the Water Masses and Transport through the Strait of Sicily, Seasonal and Interannual Variability of the Western Mediterranean Sea Coastal and Estuarine Studies, 46 (1994) 33-45, Copyright 1994 by the American Geophysical Union.

[16] May P.W., Climatological flux estimates in the Mediterranean Sea, Part I, Winds and wind stress, NORDA Tech. Rep., Nav. Oceanogr. Atmos. Res. Lab. Mississippi, 54 (1982) 56 p.

[17] MedOc Group, Observation of formation of deep water in the Mediterranean Sea, Nature 227 ( 1970) 103\%-1040.

[18] Millot C.. Circulation in the western Mediterranean Sea, Oceanologica Acta, 10, 2 (1987) 143-149.
191 Millot C.. Models and date: A synergetic approach in the wes. tern Mediterranean, in: Malanotte-Rizroli P., Robinson A.R (Eds.). Ocean Processes in Climate Dynamics: Global and Mediterranean Examples. Kluwer Acad.. Norwell. Mass. 1994. pp. 407-425.

20] Molcard, Ozturgut. Oceanography of the Strait of Sicily. SACLANT Centre Report. SACLANT Indersea Research Centre, La Spezia, Italy. 1972.

[21] Newmann G., Pierson W.J.Jr., Principles of physical Oceanography, Prentice Hall Ed.. 1966, 545 p.

[22] Perilli A., Rupolo V., Salusti E. Satellite investigation of a cyclonic gyre in the central Tyrrhenian Sea (Western Mediterrancan Sea), J. Gcophys. Res. 100, C2 (1995) 2487-2499.

[23] Pierini S.. Simioli A., A Wind-Driven Circulatin Model of the Tyrrhenian Sea area, In press in J. Mar. Syst. (1998).

[24] Serravall R., Potential Vorticity and applications in the Mediterranean Sea. Thesis. Dept. Physics, Univ. Rome Lil Sapienza, 1995. 119 p.

[25] Serravall R, Cruise AIS96: Ship-board Acoustic Doppler Current Profiler (ADCP) measurements in the Strait of Sicily and Ionian Sea, SRA (Summer Research Assistant) Report, SACLANT Undersea Research Centre, La Spezia, Italy (1996) $1-37$.

[26] TEMPO Group, Tyrrhenian Eddy Multi-platform Observation, 1989, Experimental Inventory of the measurements and preliminary results. Tech. Rep. I (1991) 69 p.

[27] Wajsowicz R.C.. Gill A.E. Adjustment of the Ocean under Buoyancy Forces, Part I: The Role of Kelvin Waves, J. Phys. Oceanogr. 16 (1986) 2097-2114.

[28] Wüst G.. On the Vertical Circulation of the Mediterranean Sea. J. Geophys. Res. 66 (1961) 10, 3261-3271.

[29] Wu P., Haines K., Modeling the dispersal of Levantine Intermediate Water and its role in Mediterranean deep water formation, J. Geophys. Res. 101, C3, (1996) 6591-6607. 